\title{
sciendo
}

\section{Retinal changes in patients with angina pectoris and anginal equivalents: a study of patients with normal coronary angiography}

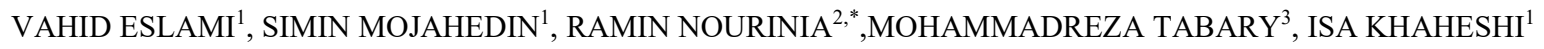 \\ ${ }^{1}$ Cardiovascular Research Center, Shahid Beheshti University of Medical Sciences, Tehran, Iran \\ ${ }^{2}$ Ophtalmic Research Center, Shahid Beheshti University of Medical Sciences, Tehran, Iran \\ ${ }^{3}$ Experimental Medicine Research Center, Tehran University of Medical Sciences, Tehran, Iran
}

\begin{abstract}
Background and aims. Approximately $10-30 \%$ of the patients with typical symptoms of angina pectoris have normal angiography showing normal macrovasculature. In these patients, however, the microvascular problems should be monitored. Hence, the main aim of this study is to evaluate retinal changes in normal angiographic patients.

Methods. In this descriptive cross-sectional study, 60 normal angiographic patients with typical chest pain or anginal equivalents visiting Modarres Hospital Cardiology Research Center between 2018 and 2019 were enrolled and retinal changes were determined in Labbafinejad Hospital by Optical Coherence Tomography Angiography using Foveal Avascular Zone (FAZ), Superficial Vascular Density (SVD), and Deep Vascular Density (DVD).

Results. The results of this study demonstrated that FAZ was normal in all subjects, but SVD and DVD were abnormal in $45 \%$ and $8.3 \%$, respectively. Totally, $18.5 \%$ and $66.7 \%$ showed abnormal SVD among stable angina (SA) and unstable angina (UA) cases, respectively $(\mathrm{P}<0.001)$. There was no statistically significant difference between abnormal DVD in SA and UA cases $(P=0.058)$. Abnormal SVD was significantly more common among diabetic patients $(\mathrm{P}<0.001)$, while DVD was not related to diabetes presence in the study population $(\mathrm{P}>0.05)$. Moreover, abnormal SVD was more common among patients with chest pain $(\mathrm{P}=0.036)$, while there was no significant difference for DVD $(\mathrm{P}=0.371)$. Interestingly, abnormal ECG was associated with both abnormal DVD and SVD.

Conclusions. The results of this study showed that nearly half of the patients with angina pectoris or anginal equivalents who revealed normal angiographic findings may suffer from retinal changes. Thus, retinal assessment is needed in these patients to evaluate microvascular changes.
\end{abstract}

Key words: retinal changes, angiography, microvascular involvement, coronary artery disease, angina pectoris.

\section{INTRODUCTION}

High burden of cardiovascular diseases (CVDs), especially coronary artery disease, is a global issue with extended rate of mortality and morbidity as well as health costs $[1,2]$. It has been reported that there were 422.7 million cases of CVDs and 17.92 million related deaths worldwide in 2015 [3]. Also, ischemic heart disease (IHD) is believed to be the leading cause of CVD health loss globally. It is projected that IHD-related deaths will increase to more than 9 million global death in 2030 [4]. Recognition of high-risk subjects has some limitations and further studies are required to acknowledge the vital factors and at the same time rule out the effect of confounding factors $[5,6]$. Such attempts to determine the high-risk groups are essential in all patients, especially in cases with insufficient number of known risk factors [7-9].
These methods for the determination of the risk factors should be easy and feasible [9].

It is assumed that retinal vessels may resemble microvasculature of coronary arteries and can reflect both the microvascular injuries and their course of progression [9]. Also, some studies have shown the association between macrovascular disease of coronary arteries and retinal small vessels [10]. These findings in micro-circulation alterations such as micro-aneurysm, focal and general stenosis, and arteriolar or venular nicking may predict the risk of cardiovascular events [11].

Retinopathy can be seen as cotton wool spots, hemorrhage, micro-aneurysm, macular edema, and exudates [12]. Despite proposed association between retinal disease and systemic artery diseases, the ophthalmoscopy is not accepted as a routine procedure because it is not a quantitative and objective method $[12,13]$. Nevertheless, state-of-the-art methods 
assessing retinal vessels and their structures are available and may have different applicability in this era $[12,13]$.

Macula is the main retinal part that can be assessed in terms of retinal function and structure evaluation by optical coherence tomography angiography (OCTA) and by reporting the dimensions of foveal avascular zone [14]. Nearly 10-20\% of patients with chest pain undergoing angiography may have normal findings [15]. Among them, subjects with exertion chest pain and ST-segment depression in ECG or impaired myocardial perfusion are considered as X-syndrome [15]. In these patients, however, the microvascular problems should be monitored, while there is no definite tool to assess these changes and predict future macrovascular problems. Hence, the main aim of this study was to evaluate retinal changes in patients with normal coronary angiography.

\section{MATERIALS AND METHODS}

In this descriptive cross-sectional study, 60 consecutive patients with normal coronary angiography or non-significant findings that had typical chest pain or anginal equivalents were enrolled. These patients, also, had abnormal noninvasive tests such as ECG, echocardiography, and exercise tests. All the patients referred to Modarres Hospital Cardiology Research Center (Tehran, Iran) between 2018 and 2019. We excluded the cases with slow-flow phenomenon, coronary ectasia or incomplete data.

This study was approved by local ethical committee of Shahid Beheshti University of Medical Sciences and written consent was obtained from all patients. All the research protocols were in accordance with the ethical guidelines of the 1975 Declaration of Helsinki. Complete history was taken and recorded in the checklists. Retinal changes including atherosclerosis and retinopathy were determined in Labbafinejad Hospital by optical coherence Tomography Angiography (OCTA). Accordingly, foveal avascular zone (FAZ), superficial vascular density (SVD), and deep vascular density (DVD) were assessed. The only ophthalmologist was blind to the study protocol during retinal assessments.

Normal coronary artery was defined by conventional angiography method; in other words, cases with no 'endoluminal irregularities' or 'no significant $(<20 \%)$ stenosis' were considered normalangiographic. Also, mild coronary artery disease was defined as casese with stenosis between $20 \%$ and $50 \%$ in coronary arteries. OCTA provides some depth-resolved images of the blood flow in the retina and choroid with definite details. This multimodal imaging methods is used for the evaluation of retinal diseases. FAZ was defined as the round/ oval capillary-free region within the macula area. SVD was also defined as the proportion of the the sample area occupied by vascular lumens after binary reconstruction of images. DVD was defined as deep capillary plexuses of the sample area occupied by vascular lumens following binary reconstruction of the images. Normal ranges were those in mean \pm standard deviation in normal populations.

Data analysis was performed in SPSS version 26.0. Utilized statistical tests were KolmogorovSmirnov, Independent-Sample-T, Chi-Square, and Fisher tests. P-values under 0.05 were considered as statistically significant.

\section{RESULTS}

The mean age of patients ( 21 males, 39 females) was $66.2 \pm 6.9$ years. Patients' baseline characteristics are summarized in Table 1.

Retinal findings included FAZ, DVD, and SVD. FAZ and diameter were both normal in all subjects, and to better explain, it can be mentioned that it was in a range of mean \pm standard deviation in all subjects. However, SVD and DVD were abnormal in $45 \%$ and $8.3 \%$ of patients, respectively. As shown in Table 2, older age was related to abnormal SVD $(\mathrm{P}=0.036)$, but not to abnormal DVD $(\mathrm{P}=0.088)$.

As shown in Table 3 and Table 4, sex was not associated with SVD and DVD findings ( $\mathrm{P}>0.05)$. Also, history of hypertension had no significant association with either SVD or DVD results $(\mathrm{P}>0.05)$. Abnormal SVD was significantly more common among diabetic patients $(\mathrm{P}<0.001)$, while DVD was not related to diabetes presence in patients $(\mathrm{P}>0.05)$. Moreover, hyperlipidemia and smoking were not related to DVD and SVD results $(\mathrm{P}>0.05)$.

Totally, $18.5 \%$ and $66.7 \%$ among stable angina (SA) and unstable angina (UA) cases revealed abnormal SVD with significant difference $(\mathrm{P}<0.001)$. There was no statistically significant difference between abnormal DVD in SA and UA cases $(\mathrm{P}=0.058)$. As shown in Table 5, abnormal SVD was more common among patients with chest pain $(\mathrm{P}=0.036)$, while there was no significant difference for DVD $(\mathrm{P}=0.371)$. 
Table 1

Patients' baseline characteristics

\begin{tabular}{lcc}
\hline & Number & Percent \\
\hline Male & 21 & $35 \%$ \\
Female & 39 & $65 \%$ \\
\hline HTN & 47 & $78.33 \%$ \\
\hline HTN (male) & 14 & $23.33 \%$ \\
HTN (female) & 33 & $55 \%$ \\
\hline DM (male) & 27 & $45 \%$ \\
DM (female) & 9 & $15 \%$ \\
\hline HLP & 18 & $30 \%$ \\
\hline HLP (male) & 24 & $40 \%$ \\
\hline SLP (female) & 8 & $13.33 \%$ \\
\hline Smoking & 16 & $26.66 \%$ \\
Smoking (male) & 12 & $20 \%$ \\
\hline Abbale) & 8 & $13.33 \%$ \\
\hline
\end{tabular}

Abbreviations: HTN, hypertension; DM, diabetes mellitus; HLP, hyperlipidemia.

Table 2

SVD and DVD results by age among patients

\begin{tabular}{lcccc}
\hline & & \multicolumn{2}{c}{ Age } & P-Value \\
\hline \multirow{2}{*}{ SVD } & Mean & Standard Deviation & 0.036 \\
& Normal & 64.8 & 7.1 & 6.2 \\
\multirow{2}{*}{ DVD } & Abnormal & 68.6 & 6.5 & 0.088 \\
\hline
\end{tabular}

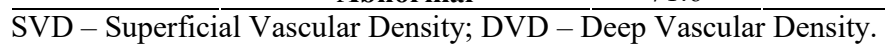

Table 3

DVD results by categorical data

\begin{tabular}{|c|c|c|c|c|c|c|}
\hline & \multicolumn{6}{|c|}{ DVD } \\
\hline & & \multicolumn{2}{|c|}{ Normal } & \multicolumn{2}{|c|}{ Abnormal } & P-Value \\
\hline & & Count & Percent & Count & Percent & \\
\hline \multirow{2}{*}{ Sex } & Male & 21 & $100.0 \%$ & 0 & $.0 \%$ & 0.152 \\
\hline & Female & 34 & $87.2 \%$ & 5 & $12.8 \%$ & \\
\hline \multirow{2}{*}{ Hypertension } & Positive & 42 & $89.4 \%$ & 5 & $10.6 \%$ & 0.575 \\
\hline & Negative & 13 & $100.0 \%$ & 0 & $.0 \%$ & \\
\hline \multirow{2}{*}{ Diabetes Mellitus } & Positive & 24 & $88.9 \%$ & 3 & $11.1 \%$ & 0.649 \\
\hline & Negative & 31 & $93.9 \%$ & 2 & $6.1 \%$ & \\
\hline \multirow{2}{*}{ Hyperlipidemia } & Positive & 22 & $91.7 \%$ & 2 & $8.3 \%$ & 1.000 \\
\hline & Negative & 33 & $91.7 \%$ & 3 & $8.3 \%$ & \\
\hline \multirow{2}{*}{ Smoking } & Positive & 12 & $100.0 \%$ & 0 & $.0 \%$ & 0.572 \\
\hline & Negative & 43 & $89.6 \%$ & 5 & $10.4 \%$ & \\
\hline
\end{tabular}

DVD - Deep Vascular Density.

Table 4

SVD results by categorical data

\begin{tabular}{|c|c|c|c|c|c|c|}
\hline & & \multicolumn{4}{|c|}{ SVD } & \multirow{3}{*}{ P-Value } \\
\hline & & \multicolumn{2}{|c|}{ Normal } & \multicolumn{2}{|c|}{ Abnormal } & \\
\hline & & Count & Percent & Count & Percent & \\
\hline \multirow{2}{*}{ Sex } & Male & 15 & $71.4 \%$ & 6 & $28.6 \%$ & 0.061 \\
\hline & Female & 18 & $46.2 \%$ & 21 & $53.8 \%$ & \\
\hline \multirow{2}{*}{ Hypertension } & Positive & 23 & $48.9 \%$ & 24 & $51.1 \%$ & 0.073 \\
\hline & Negative & 10 & $76.9 \%$ & 3 & $23.1 \%$ & \\
\hline \multirow{2}{*}{ Diabetes Mellitus } & Positive & 7 & $25.9 \%$ & 20 & $74.1 \%$ & 0.001 \\
\hline & Negative & 26 & $78.8 \%$ & 7 & $21.2 \%$ & \\
\hline \multirow{2}{*}{ Hyperlipidemia } & Positive & 14 & $58.3 \%$ & 10 & $41.7 \%$ & 0.672 \\
\hline & Negative & 19 & $52.8 \%$ & 17 & $47.2 \%$ & \\
\hline \multirow{2}{*}{ Smoking } & Positive & 7 & $58.3 \%$ & 5 & $41.7 \%$ & 0.795 \\
\hline & Negative & 26 & $54.2 \%$ & 22 & $45.8 \%$ & \\
\hline
\end{tabular}

SVD - Superficial Vascular Density. 
Table 5

SVD and DVD results by type of cardiac symptoms

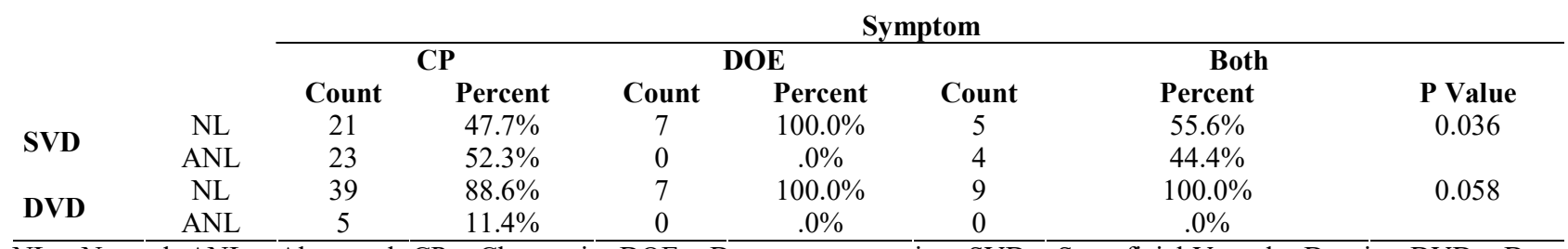

$\overline{\mathrm{NL}}$ - Normal; ANL $-\overline{\text { Abnormal; }} \overline{\mathrm{CP} \text { - Chest pain; DOE - Dyspnea on exertion; SVD - Superficial Vascular Density; DVD - Deep }}$ Vascular Density.

Percentage represent the prevalence normal and abnormal SVD or DVD in patients with each complaint. P-values are associated with the difference of abnormal SVD or DVD between columns.

As shown in Table 6, among those with abnormal and normal ECG, $73.3 \%$ and $35.5 \%$ showed abnormal SVD, respectively $(\mathrm{P}=0.011)$. Also, among those with abnormal and normal ECG, $26.7 \%$ and $2.2 \%$ had abnormal DVD with significant difference $(\mathrm{P}=0.012)$.

Table 6

SVD and DVD results by ECG findings

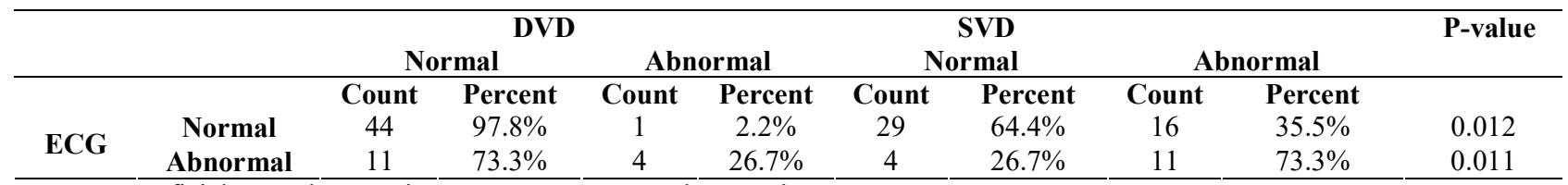

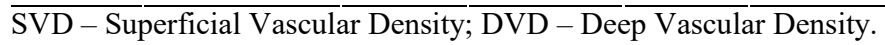

\section{DISCUSSION}

Totally up to one-third of cases with typical chest pain have normal angiography and determination of the risk factors for progression of vascular disease in these subjects is crucial [15]. In our study, SVD and DVD were abnormal and showed some differences by the type of symptoms and disease subtype. The abnormality was more common in unstable angina cases and those with chest pain.

Many studies have evaluated the correlation between coronary artery disease and retinal microvascular changes, but their findings are inconsistent. Van Hecke et al. found that there was no correlation between retinal microvascular abnormalities and endothelium-dependent flow-mediated vasodilation (a marker for endothelial function) or carotid intimamedia thickness (a marker for early atherosclerosis) [16]. The most important difference between our study and Van Hecke's is that we included patients with related cardiac symptoms of IHD; in other words, we included patients with possible clinical dysfunction of cardiovascular system, while the others of the mentioned study included patients without any clinical symptoms, and this can justify this inconsistency. On the other hand, a Chinese study found significantly decreased central retinal artery blood flow in the patients with coronary artery disease, which underscores the role of endothelial dusfunction as a mutual mechanism [17]. Possible shared mechanism proposed is systemic inflammation which affects not only coronary arteries but also retinal vessels [18].

Tedeschi-reiner et al. [19] assessed 109 Coronary Artery Disease (CAD) cases and reported that CAD severity and retinal vessel atherosclerosis were interrelated. In our study, however, we enrolled patients with normal coronary findings in angiography. Witt et al. [12] also performed a case-control study and reported that microvascular findings in retinal assessments may be utilized as a non-invasive method to predict the outcomes. However, our study was a cross-sectional one and further longitudinal studies should be carried out for outcome prediction.

Kreis et al. [20] assessed both coronary and retinal vessels angiography in 98 cases and found that there was no association between CAD severity and retinal findings. In our study, the type of coronary artery disease was related to retinal findings and unstable versus stable angina had different rate of abnormality in retinal assessments. Also, types of retinal findings were different among patients with diverse clinical symptoms. This may show that the level of coronary artery involvement may be also associatd with the degree of involvement in retinal vessels.

Wang and colleagues [21] reported that among 472 suspected cases of CAD, assessed by 
angiography, approved CAD cases had higher abnormalities in retinal evaluations with further severity. In our study, there were no comparison group and for this matter definite interpretation in this era is impossible.

A meta-analysis by Liu et al. suggests that only arteriolar caliber (but not venular) is associated with arterial function and this association become more prominent in cardiometabolic patients [22]. This may underscore the importance of shared mechanism of preclinical changes in large arteries and microcirculation. We also showed that in patients with CVD, there are some associations between CVD and retinal vessels. However, more studies are needed to clarify this association in patients with other vascular diseases, such as stroke.

Here, it should be mentioned that both retinal vessels anatomy and physiological functionality should be taken into account for risk stratification in CAD [23]. Moreover, other related complication such as stroke, heart failure, and mortality has been shown to correlate with the structure of retinal vessels, but the results are diverse and further studies are needed to develop a risk-scoring system using retinal vessels [23].

\section{CONCLUSION}

The results of this study showed that nearly half of the patients with angina pectoris or anginal equivalents who revealed normal angiographic findings may suffer from retinal changes. Thus, retinal assessment may be needed in these patients to evaluate microvascular changes. However, further studies with larger sample size and further diagnostic methods are required to attain more definite comparable results in this era.

Introducere. $10-30 \%$ dintre pacienții cu simptome tipice de angină pectorală au angiografie normală. Acești pacienți prezintă insă afectare microvasculară care trebuie evaluată. Studiul evaluează modificările microvasculare la acești pacienți.

Metode. A fost realizat un studiu descriptiv transversal în care au fost evaluați 60 de pacienți cu angiografii normale, dar cu simptome de angina pectorală sau echivalențe de angină ce s-au prezentat în spitalul Modarres între 2018 și 2019. Modificările retinale au fost evaluate la Spitalul Labbafinejad folosind tehnicile FAZ (Optical Coherence Tomography Angiography using Foveal Avascular Zone), SVD (Superficial Vascular Density) și DVD (Deep Vascular Density).

Rezultate. FAZ a fost normal la toți pacienții însă SVD și DVD au fost modificate la $45 \%$ respectiv $8,3 \%$ dintre pacienți. $18,5 \%$ și $66,7 \%$ dintre pacienții cu SVD modificat aveau angină stabilă (SA), respectiv angina instabilă (US) $(p<0,001)$. Nu s-a observat o diferență semnificativă între SA și UA privind modificările DVD. SVD anormal s-a observat mai degrabă la pacientii diabetici $(p<0,001)$, pe când DVD nu s-a observat a fi asociat cu diabetul. Modificările SVD au fost prezente mai degrabă la pacienții cu durere precordială $(p=0,036)$, dar nesemnificativă asocierea cu DVD ( $p=0,371)$. Modificările ECG s-au asociat cu modificări ale DVD și SVD.

Concluzii. Aproape jumătate din pacienții cu angină și angiografii normale au avut modificări ale circulației retinei. Evaluarea retinei la acești pacienți ar putea fi utilă în vederea evaluării afectării microvasculare.

Correspondence to: Ramin Nourinia, Ophtalmic Research Center, Shahid Beheshti University of Medical Sciences, Tehran, Iran Email: Ramin.retin@gmail.com

Address: Shahid Beheshti University G.C., Velenjak, Tehran, Iran Postal code: 1983969411

Conflict of interest declaration: The authors declare that they have no conflict of interest.

Acknowledgment: None to declare.

Funding: None to declare

Ethical consideration: All human studies have been reviewed by the ethics committee of Shahid Beheshti University of Medical Sciences and have therefore been performed in accordance with the ethical standards laid down in an appropriate version of the Declaration of Helsinki (as revised in Brazil 2013). 


\section{Authors' contributions:}

Vahid Eslami: Manuscript writing, analysis

Simin Mojahedin: Data acquisition, manuscript writing

Ramin Nourinia: Supervision, conceptualisation, final edit

Mohammadreza Tabary: Manuscript editing, data acquisition

Isa Khaheshi: Manuscript editing, data acquisition

\section{REFERENCES}

1. BAINEY KR, JUGDUTT BI. Increased burden of coronary artery disease in South-Asians living in North America. Need for an aggressive management algorithm. Atherosclerosis. 2009; 204(1):1-10.

2. WEINSTEIN MC, COXSON PG, WILLIAMS LW, PASS TM, STASON WB, GOLDMAN L. Forecasting coronary heart disease incidence, mortality, and cost: the Coronary Heart Disease Policy Model. American journal of public health. 1987; 77(11):1417-26.

3. ROTH GA, JOHNSON C, ABAJOBIR A, ABD-ALLAH F, ABERA SF, ABYU G, et al. Global, Regional, and National Burden of Cardiovascular Diseases for 10 Causes, 1990 to 2015. J Am Coll Cardiol. 2017; 70(1):1-25.

4. MATHERS CD, LONCAR D. Updated projections of global mortality and burden of disease, 2002-2030: data sources, methods and results. Geneva: World Health Organization. 2005.

5. DELAHAYE F, ROTH O, DE GEVIGNEY G. Epidemiology of acute coronary syndrome. La Revue du praticien. 2003; 53(6):607-10.

6. KOCH CG, WENG Y-S, ZHOU SX, SAVINO JS, MATHEW JP, HSU PH, et al. Prevalence of risk factors, and not gender per se, determines short-and long-term survival after coronary artery bypass surgery. Journal of cardiothoracic and vascular anesthesia. 2003; 17(5):585-93.

7. RASTGOU F, BITARAFAN-RAJABI A, FARHZADI A, YAGHOOBI N, FIROOZABADY H, MALEK H, et al. Diagnostic accuracy assessment of ST-segment displacements, chest pain and stress myocardial perfusion imaging exercise test in coronary stenosis compared with angiography findings. Iranian Heart Journal. 2012; 12(4):30-6.

8. ARAUJO ACPD, SANTOS BF, CALASANS FR, PINTO IM, OLIVEIRA DPD, MELO LD, et al. Physical stress echocardiography: prediction of mortality and cardiac events in patients with exercise test showing ischemia. Arquivos brasileiros de cardiologia. 2014; 103(5):418-25.

9. GRUNDY SM. Primary prevention of coronary heart disease: integrating risk assessment with intervention. Circulation. 1999; 100(9):988-98.

10. MCCLINTIC BR, MCCLINTIC JI, BISOGNANO JD, BLOCK RC. The relationship between retinal microvascular abnormalities and coronary heart disease: a review. The American journal of medicine. 2010; 123(4):374. e1-e7.

11. WONG TY, KLEIN R, KLEIN BE, TIELSCH JM, HUBBARD L, NIETO FJ. Retinal microvascular abnormalities and their relationship with hypertension, cardiovascular disease, and mortality. Survey of ophthalmology. 2001; 46(1):59-80.

12. WITT N, WONG TY, HUGHES AD, CHATURVEDI N, KLEIN BE, EVANS R, et al. Abnormalities of retinal microvascular structure and risk of mortality from ischemic heart disease and stroke. Hypertension. 2006; 47(5):975-81.

13. NEWSOM RS, SULLIVAN PM, RASSAM SM, JAGOE R, KOHNER EM. Retinal vessel measurement: comparison between observer and computer driven methods. Graefe's archive for clinical and experimental ophthalmology. 1992; 230(3):221-5.

14. RASSAM S, PATEL V, BRINCHMANN-HANSEN O, ENGVOLD OR, KOHNER EM. Accurate vessel width measurement from fundus photographs: a new concept. British Journal of Ophthalmology. 1994; 78(1):24-9.

15. IAFE NA, PHASUKKIJWATANA N, CHEN X, SARRAF D. Retinal capillary density and foveal avascular zone area are agedependent: quantitative analysis using optical coherence tomography angiography. Investigative ophthalmology \& visual science. 2016; 57(13):5780-7.

16. VAN HECKE MV, DEKKER JM, NIJPELS G, STOLK RP, HENRY RM, HEINE RJ, et al. Are retinal microvascular abnormalities associated with large artery endothelial dysfunction and intima-media thickness? The Hoorn Study. Clinical science. 2006; 110(5):597-604.

17. WU Y, LI S, ZU X, DU J, WANG F. Changes of central retinal artery blood flow and endothelial function in patients with coronary artery disease. Current Eye Research. 2007; 32(9):813-7.

18. CHEUNG N, WANG JJ, KLEIN R, COUPER DJ, SHARRETT AR, WONG TY. Diabetic retinopathy and the risk of coronary heart disease: the Atherosclerosis Risk in Communities Study. Diabetes Care. 2007; 30(7):1742-6.

19. TEDESCHI-REINER E, STROZZI M, SKORIC B, REINER Z. Relation of atherosclerotic changes in retinal arteries to the extent of coronary artery disease. The American journal of cardiology. 2005; 96(8):1107-9.

20. KREIS AJ, NGUYEN TT, WANG JJ, ROGERS S, AL-FIADH A, FREEMAN M, et al. Are retinal microvascular caliber changes associated with severity of coronary artery disease in symptomatic cardiac patients? Microcirculation. 2009; 16(2):177-81.

21. WANG D-Z, TANG Q, HUA Q. Prediction of coronary artery disease using pulse wave velocity and retinal artery lesions. The Tohoku Journal of Experimental Medicine. 2011; 225(1):17-22.

22. LIU M, WAKE M, WONG TY, HE M, XIAO Y, BURGNER DP, et al. Associations of retinal microvascular caliber with intermediate phenotypes of large arterial function and structure: A systematic review and meta-analysis. Microcirculation. 2019; 26(7):e12557.

23. GUO S, YIN S, TSE G, LI G, SU L, LIU T. Association Between Caliber of Retinal Vessels and Cardiovascular Disease: a Systematic Review and Meta-Analysis. Curr Atheroscler Rep. 2020; 22(4):16.

Received $1^{\text {st }}$ October 2020 